\title{
INFLUENCE OF ELEVATED CO2 ASSOCIATED WITH CHICKPEA ON GROWTH PERFORMANCE OF GRAM CATERPILLAR, HELICOVERPA ARMIGERA (HÜB.)
}

\author{
ABDUL KHADAR, B. ${ }^{1}$ *- PRABHURAJ, A. ${ }^{1}$ - SRINIVASA RAO, M. $^{2}$ - SREENIVAS, AG. ${ }^{1}$ - \\ NAGANAGOUD A ${ }^{1}$ \\ ${ }^{1}$ Department of Agricultural Entomology, University of Agricultural Sciences, \\ Raichur-584 102, India \\ ${ }^{2}$ Central Research Institute for Dryland Agriculture, \\ Santhosh Nagar, Hyderabad - 500 059, India \\ *Corresponding author \\ e-mail:ahbiradar111@gmail.com \\ (Received $29^{\text {th }}$ Jan 2013; accepted $22^{\text {nd }}$ July 2014)
}

\begin{abstract}
Influence of increased $\mathrm{CO}_{2}$ concentrations (550 and 700 ppm) on host (Chickpea, Cicer arietinum L.) and its insect herbivore (Gram caterpillar, Helicoverpa armigera (Hüb.)) was studied in relation to ambient $\mathrm{CO}_{2}(380 \mathrm{ppm})$ concentration under laboratory conditions. The foliar chemistry of chickpea under elevated $\mathrm{CO}_{2}$ revealed low nitrogen and high carbon content with increased $\mathrm{C}: \mathrm{N}$ ratio but no change in phenol content. This alteration in food quality significantly affected the growth parameters of $H$. armigera in the form of increased food consumption, gain in larval weight and more fecal matter production. Larval duration was also extended by one day under elevated $\mathrm{CO}_{2}$ over ambient. Further, reduction in the fecundity (535 eggs/ female) was observed in the individuals raised under elevated conditions compared to ambient situation (580 eggs/ female). Diluted quality of food had a significant effect on growth performance indices of insect. Increase in approximate digestibility and relative consumption rate by the larva was observed under elevated $\mathrm{CO}_{2}$ situation. The reduced efficiency of conversion of ingested food (35.88 \%) and digested food (37.88 \%) was observed under similar situation. As a result, the relative growth rate was down by $5.22 \%$ and $6.20 \%$ under both elevated $\mathrm{CO}_{2}$ conditions. In a nutshell, it can be concluded that increased $\mathrm{CO}_{2}$ concentrations has the negative effect on the growth and development of $H$. armigera.
\end{abstract}

Key words: $\mathrm{CO}_{2}$ concentration, climate change, Helicoverpa armigera, chickpea, developmental biology

\section{Introduction}

Gram caterpillar, Helicoverpa armigera (Hub.) is a highly polyphagous pest known to cause serious economic damage to many field crops of arid and semiarid tropics across the globe. In India, it is a major pest of pigeon pea, chickpea, sunflower, sorghum and tomato crops. In Southern states of India, it breeds throughout the year completing over eight generations. The first generation usually starts in early June, coinciding with the onset of pre-monsoon showers either from the adults possibly emerging from diapausing pupae or from larvae that have been surviving on off season crops and weeds during summer. Initially, the species survives in low numbers on weeds, early-sown corn, sorghum, mung bean and groundnut but later builds up the population before shifting to pigeon pea in October-November and then to chickpea in November-March. Chickpea, the last notable crop of the season grown extensively across India, acts as a main breeding ground for $H$. armigera harbouring at least two generations. Thus, chickpea plays a crucial role in the mass breeding and sustenance of the pest for the next season (Bhatnagar, 1980). Success of carryover of the pest to the 
next season mainly depends on fitness of the host on which it completes the last generation and the environmental condition during the transitional period.

The present change in climate is closely linked with the rise in atmospheric carbon dioxide $\left(\mathrm{CO}_{2}\right)$ levels from 280 to $387 \mathrm{ppm}$ since the start of the Industrial Revolution. And current levels of $\mathrm{CO}_{2}$ are expected to double by 2100 (IPCC 2007). Such rise in $\mathrm{CO}_{2}$ levels affects the biological system of living organisms, including insects (Guerenstein and Hildebrand, 2008). Since fitness of any herbivorous insects depends on nutritional status of their host, any change in the quality of host plants can affect their growth, development, population dynamics and survival. The extent of growth, yield and biochemical responses of plants to elevated $\mathrm{CO}_{2}$ depends on the photosynthetic pathway. Crops with $\mathrm{C}_{3}$ photosynthesis respond markedly to increasing $\mathrm{CO}_{2}$ concentrations by inhibiting photorespiration, making photosynthesis more efficient, however, leaf nitrogen and protein concentrations ultimately decrease by more than $12 \%$ (Ainsworth and Long 2005). Such a loss of nitrogen and protein significantly diminishes the nutritional value of plant affecting growth and development of insect herbivores either directly or indirectly. In contrast, plants with $\mathrm{C}_{4}$ photosynthesis will respond little to rising atmospheric $\mathrm{CO}_{2}$ due to saturation of photosynthesis (Leon Hartwell and Vara Prasad, 2004).

Chickpea (Cicer arietinum L.) being a $\mathrm{C}_{3}$ crop makes an interesting candidate to study the nutritional changes occurring due to altered $\mathrm{CO}_{2}$ concentrations in its growth environment and its effect on the developmental and reproductive biology of one of its important pests, $H$. armigera to assess its pest status in next generations.

\section{Materials and methods}

\section{Open top chambers (OTCS)}

Three Open top chambers (OTCs) of $4 \times 4 \times 4 \mathrm{~m}$ dimensions, are established at Central Research Institute for Dryland Agriculture (CRIDA), Hyderabad $\left(17^{\circ} 38^{\prime} \mathrm{N} ; 78^{\circ}\right.$ $47^{\prime}$ E). Elevated $\mathrm{CO}_{2}$ concentrations of $550 \pm 25 \mathrm{ppm}$ (Condition I) and $700 \pm 25 \mathrm{ppm}$ (condition II) were maintained in two chambers and ambient $\mathrm{CO}_{2}(380 \pm 25 \mathrm{ppm})$ in the third chamber. Carbon dioxide gas supplied to these chambers was maintained at set levels using manifold gas regulators, pressure pipelines, solenoid valves, rotameters, sampler pump, $\mathrm{CO}_{2}$ analyzer, $\mathrm{PC}$ linked Program Logic Control (PLC) and Supervisory Control and Data Acquisition (SCADA). The fully automated OTCs are first of their kind in India, which not only maintains the desired level of $\mathrm{CO}_{2}$ but also the temperature and relative humidity (Vanaja et al., 2006).

Seeds of Chickpea Var. MNK-1 (Kabuli type) were sown in plastic pots $(19 \mathrm{~cm}$ height, $17 \mathrm{~cm}$ diameter) and were kept in all the three OTCs during October 2011. Plant density and health were maintained by the adoption of proper agronomic practices.

\section{Biochemical analysis of chickpea}

Leaves of chickpea from respective OTCs were analyzed to estimate carbon, nitrogen, $\mathrm{C}$ : $\mathrm{N}$ ratio and phenol content through standard procedures. To estimate carbon, nitrogen and phenol content, leaf samples taken from 60 days old plants were dried at $80^{\circ} \mathrm{C}$ and subsequently ground to powder. Organic carbon was determined by Walkley Black method (1934) and nitrogen by Kjeldhahl using block digestion and steam distillation method (McKenzie, 1994). C: $\mathrm{N}$ ratio was analyzed by using $\mathrm{CHN}$ 
analyser (Elementar Analysen system GmbH, Germany) and total phenol was estimated by Folin-Denis method (Anderson and Ingram, 1993).

\section{Feeding trials}

Culture of $H$. armigera procured from CRIDA laboratory was maintained on artificial diet, which was prepared using chickpea leaves in a controlled chamber at $27^{\circ}$ $\mathrm{C}$ with a 14-h day/ 10-h night cycle. Light intensity inside the chamber during the $14 \mathrm{~h}$ day period was maintained at $550 \mu \mathrm{mol} \mathrm{m} \mathrm{m}^{-1}$ with relative humidity of $60 \%$ (day) and $70 \%$ (night).

Eggs from the stock culture showing germ band development were surface sterilized with 10 per cent formalin for 10 minutes and washed under running tap water. Upon hatching, a day-old neonates was grouped into three batches; each batch containing 48 larvae. One batch was reared in the growth chamber maintained at ambient (380 ppm) $\mathrm{CO}_{2}$ concentration on chickpea leaf composed artificial diet. Whereas, other two batches were reared separately in two different growth chambers maintained at $550 \mathrm{ppm}$ and $700 \mathrm{ppm} \mathrm{CO}_{2}$ concentrations. From fourth day onwards, larvae were bred individually by transferring them into multi cavity rearing trays (each tray having six well) on preweighed artificial diet prepared out of chickpea leaves harvested from OTCs maintained with respective $\mathrm{CO}_{2}$ concentrations. Overall, 144 larvae were reared in all the three $\mathrm{CO}_{2}$ condition with each individual larva representing a replication. On every alternative day, until the completion of the larval stage, weight of unfed artificial diet was recorded and removed. At the same time, fresh pre-weighed artificial diet was provided to individual larva. The larval and fecal matter weight $(\mathrm{mg})$ was also recorded at the time of providing fresh food. After cessation of feeding which indicates the completion of larval stage, the larval duration was noted, and pupae were weighed and sexed. A pair of male and female pupae was kept separately in a plastic jar $(22 \mathrm{~cm}$ diameter, $30 \mathrm{~cm}$ height) to study the reproductive biology.

In each condition, eight pairs of $H$. armigera moths were used to study the reproductive biology. Moths were provided with 10 per cent honey solution as adult food. The mouth of the container was closed with black cotton cloth to facilitate oviposition. Eggs laid on the cloth were collected everyday with the help of fine camelhair brush and counted.

The insect performance indices were determined using the data generated from larval weight, quantity of food ingested and weight of fecal matter excreted (Waldbauer, 1968 and Srinivasa Rao et al., 2009). Relative growth rate (RGR, in $\mathrm{mg} \mathrm{mg}^{-1} \mathrm{~d}^{-1}$ ), relative consumption rate (RCR, mg mg ${ }^{-1} \mathrm{~d}^{-1}$ ), efficiency of conversion of ingested food (ECI, $\%$ ), efficiency of conversion of digested food (ECD, \%) and approximate digestibility $(\mathrm{AD}, \%)$ were computed.

\section{Data analysis}

All the treatments were replicated forty eight times $(n=48)$, and results were presented as the mean value of each treatment \pm standard deviation. The effects of $\mathrm{CO}_{2}$ concentrations on larval parameters were analyzed using one-way ANOVA. Treatment means were compared and separated using the least significant difference (LSD) at $\mathrm{p}<0.01$. The data on weight of food ingested, larval weight, fecal matter weight, larval duration, pupal weight and fecundity were analyzed using ANOVA with the help of STAR (Statistical tool for agriculture research), version 1.00 . 


\section{Results}

\section{Biochemical analysis of chickpea leaves}

In the present study, the nutritional quality of chickpea leaves differed significantly across all the three $\mathrm{CO}_{2}$ concentrations. Leaf nitrogen content was distinctly lower $(2.92$ and $3.21 \%)$ in elevated $\mathrm{I}(550 \pm 25 \mathrm{ppm})$ and II $(700 \pm 25 \mathrm{ppm}) \mathrm{CO}_{2}$ conditions compared to ambient $(3.88 \%)\left(\mathrm{F}_{2,4}=749.39 ; \mathrm{P}<0.01\right)$ (Fig. 1a) However, the carbon content of leaf tissue increased significantly $\left(\mathrm{F}_{2,4}=290.07 ; \mathrm{P}<0.01\right)$ to $43.13 \%(700$ ppm) and $40.46 \%(550 \mathrm{ppm})$ under increased $\mathrm{CO}_{2}$ over ambient $\mathrm{CO}_{2}(33.99 \%)$ (Fig. $1 b)$ and resulted in a significant increase of $\mathrm{C}: \mathrm{N}$ ratio (Fig. 1c). In contrast, the phenol content did not vary significantly across $\mathrm{CO}_{2}$ conditions $\left(\mathrm{F}_{2},{ }_{4}=3.00 ; \mathrm{P}>0.05\right)$ (Fig. 1d).

\section{Larval growth performance}

Total consumption of the food (diet) by $H$. armigera larvae differed significantly across $\mathrm{CO}_{2}$ concentrations $\left(\mathrm{F}_{47},{ }_{94}=5332.83 ; \mathrm{P}<0.01\right)$. The mean food consumption was substantially higher in larvae fed on the diet prepared from chickpea grown at 550 (1887.5 mg) and $700 \mathrm{ppm}(1997.5 \mathrm{mg})$ over $380 \mathrm{ppm}(1099.5 \mathrm{mg})$ of $\mathrm{CO}_{2}$ concentrations. Similar trend was reflected in average weight gain by the larva $\left(\mathrm{F}_{47},{ }_{94}=\right.$ 49.84; P < 0.01) under elevated I (381.25 mg), and elevated II (384.16 mg) condition compared to ambient $(367.91 \mathrm{mg})$ condition. Fecal matter released by larvae was considerably more under elevated I $(602.50 \mathrm{mg})$ and elevated II $(597.70 \mathrm{mg})$ over ambient $(372.29 \mathrm{mg})$ condition $\left(\mathrm{F}_{47,}, 94=4567.27 ; \mathrm{P}<0.01\right)$. The total larval development (time taken from hatching to pupation) was extended (15.16 and 15.27 days) significantly $\left(\mathrm{F}_{47}, 94=184.60 ; \mathrm{P}<0.01\right)$ under elevated conditions over ambient (14.06 days). The pupal weight did not vary across $\mathrm{CO}_{2}$ concentrations (Table 1).

Table 1. Effect of elevated $\mathrm{CO}_{2}$ on growth and development of $\mathrm{H}$. armigera on chickpea leaf mediated artificial diet

\begin{tabular}{llllll}
\hline $\begin{array}{l}\mathbf{C O}_{2} \\
\text { concentration } \\
\text { (ppm) }\end{array}$ & $\begin{array}{l}\text { Total } \\
\text { consumed (mg) }\end{array}$ & $\begin{array}{l}\text { diet } \\
\text { Larval } \\
\text { weight }(\mathbf{m g})\end{array}$ & $\begin{array}{l}\text { FM produced } \\
(\mathbf{m g})\end{array}$ & $\begin{array}{l}\text { Larval } \\
\text { duration (days) }\end{array}$ & $\begin{array}{l}\text { Pupal } \\
\text { (g) }\end{array}$ \\
\hline 380 (Ambient) & $1099.50 \pm 52.24$ & $367.91 \pm 9.66$ & $372.29 \pm 9.94$ & $14.06 \pm 0.24$ & $0.257 \pm 0.004$ \\
550 (Elevated-I) & $1887.50 \pm 24.45$ & $381.25 \pm 7.61$ & $602.50 \pm 18.73$ & $15.16 \pm 0.37$ & $0.258 \pm 0.005$ \\
700 (Elevated-II) & $1997.50 \pm 50.71$ & $384.16 \pm 4.98$ & $597.70 \pm 12.92$ & $15.27 \pm 0.44$ & $0.259 \pm 0.006$ \\
\hline F 47,94 & 5332.83 & 49.84 & 4567.27 & 184.60 & $\mathrm{NS}$ \\
$\mathrm{P}$ & $\mathrm{P}<0.01$ & $\mathrm{P}<0.01$ & $\mathrm{P}<0.01$ & $\mathrm{P}<0.01$ & - \\
$\mathrm{CV}(\%)$ & 2.80 & 2.25 & 2.57 & 2.30 & - \\
\hline
\end{tabular}



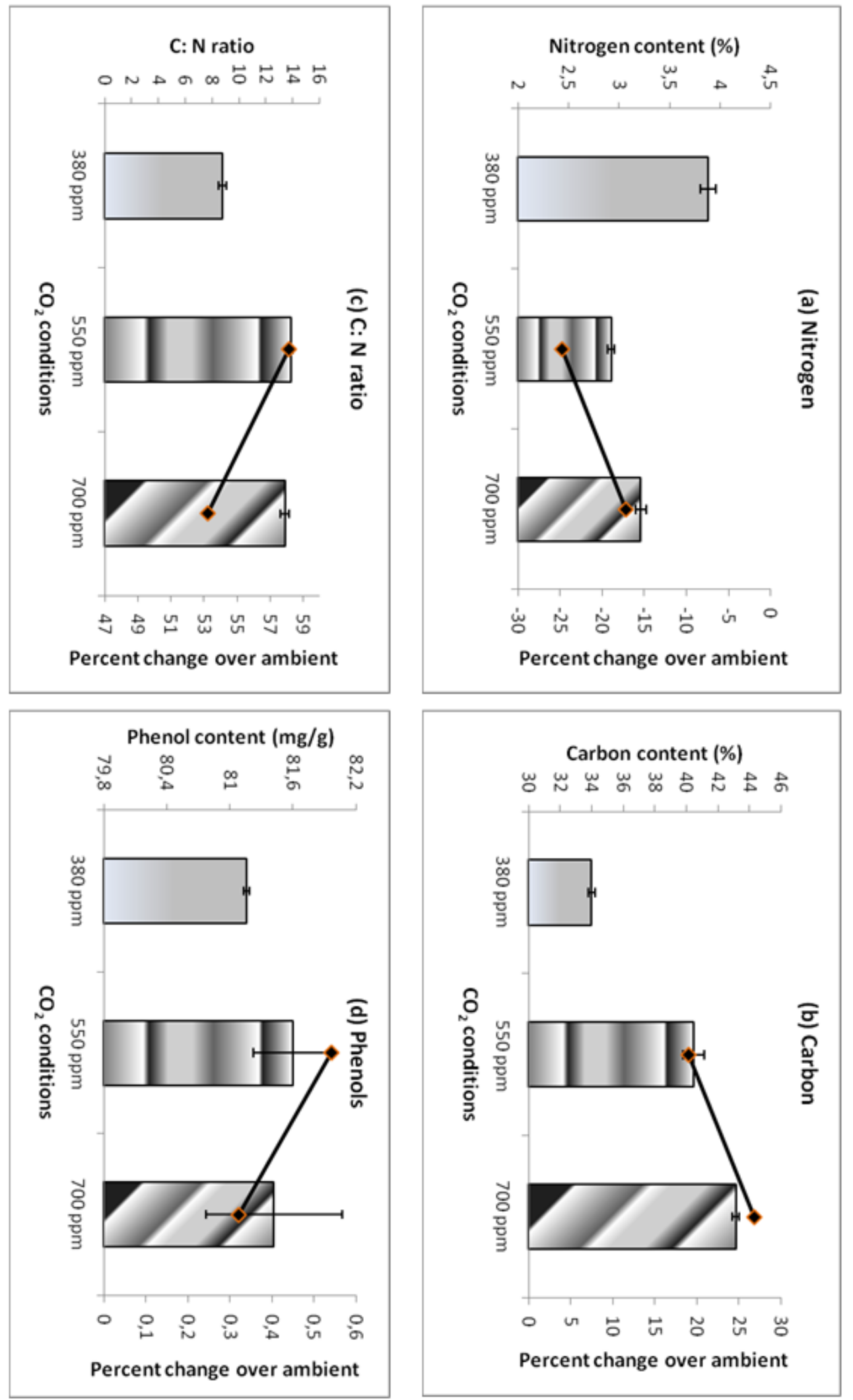

Figure 1. Biochemical changes in chickpea foliage under different $\mathrm{CO}_{2}$ conditions (a) Nitrogen (b) Carbon (c) C: N ratio and (d) Phenol content 
The approximate digestibility (AD) of the foliage by larvae was increased by about 2 $\%$ over ambient $(67.81 \%)$ condition $\left(\mathrm{F}_{47}, 94=96.36 ; \mathrm{P}<0.01\right)$. The efficiency of conversion of ingested food (ECI) was significantly lower (42.47 and $41.08 \%)$ under elevated I and II conditions, compared to ambient (64.07\%). This was reflected in significant $\left(\mathrm{F}_{47}, 94=2824.30 ; \mathrm{P}<0.01\right)$ lowering of efficiency of conversion of digested food (ECD) by the larvae under elevated conditions (61.54 and 58.71\%) compared to ambient $(94.51 \%)$. The relative consumption rate $(\mathrm{RCR})$ was higher $\left(\mathrm{F}_{47},{ }_{94}=3174.26\right.$; $\mathrm{P}<0.01)$ under both elevated concentrations with an average of $52-53 \mathrm{mg} / \mathrm{mg} / \mathrm{day}$ over ambient $(36 \mathrm{mg} / \mathrm{mg} /$ day $)$. The significant lower $\left(\mathrm{F}_{47},{ }_{94}=44.85 ; \mathrm{P}<0.01\right)$ relative growth rates (RGR) of larvae were observed under elevated I and II concentrations (22.13 and $21.90 \mathrm{mg} / \mathrm{mg} /$ day) compared to ambient $(23.35 \mathrm{mg} / \mathrm{mg} /$ day) (Table 2, Fig. 2). The females emerged from both elevated $\mathrm{CO}_{2}$ conditions produced the lower number of eggs 535 and 538 eggs/female compared to 580 eggs/female under ambient $\mathrm{CO}_{2}$ concentration $\left(\mathrm{F}_{7,14}=17.56 ; \mathrm{P}<0.01\right)($ Fig. 3).

Table 2. Effect of elevated $\mathrm{CO}_{2}$ on growth performance or indices of $\mathrm{H}$. armigera

\begin{tabular}{llllll}
\hline & \multicolumn{5}{c}{ Life history parameters/ indices } \\
\cline { 2 - 6 } CO$_{2}$ conc. (ppm) & AD (\%) & ECI (\%) & ECD (\%) & $\begin{array}{c}\text { RGR } \\
(\mathbf{m g} / \mathbf{m g} / \mathbf{d a y})\end{array}$ & $\begin{array}{c}\text { RCR } \\
(\mathbf{m g} / \mathbf{m g} / \mathbf{d a y})\end{array}$ \\
\hline 380 (Ambient) & $67.81 \pm 1.08$ & $64.07 \pm 2.48$ & $94.51 \pm 4.27$ & $23.35 \pm 0.96$ & $36.46 \pm 0.87$ \\
550 (Elevated-I) & $69.02 \pm 0.62$ & $42.47 \pm 1.34$ & $61.54 \pm 1.97$ & $22.13 \pm 0.88$ & $52.16 \pm 1.13$ \\
700 (Elevated-II) & $69.98 \pm 0.60$ & $41.08 \pm 1.16$ & $58.71 \pm 1.69$ & $21.90 \pm 0.97$ & $53.30 \pm 1.73$ \\
\hline F 47, 94 & 96.36 & 2979.59 & 2524.30 & 44.85 & 3174.26 \\
P Value & $\mathrm{P}<0.01$ & $\mathrm{P}<0.01$ & $\mathrm{P}<0.01$ & $\mathrm{P}<0.01$ & $\mathrm{P}<0.01$ \\
CV (\%) & 1.11 & 3.32 & 3.83 & 3.60 & 2.45 \\
\hline
\end{tabular}

$\mathrm{AD}=$ Approximate Digestibility $; \quad \mathrm{ECI}=$ Efficiency of Conversion of Ingested food $\mathrm{ECD}=$ Efficiency of Conversion of Digested food; $\quad$ RGR = Relative Growth Rate; RCR = Relative Consumption Rate.

\section{Discussion}

Alteration in phytochemistry of plants under the elevated $\mathrm{CO}_{2}$ concentrations is well documented (Hunter 2001). Irrespective of the biochemical pathway $\left(\mathrm{C}_{3}\right.$ and $\left.\mathrm{C}_{4}\right)$, crop exhibit reduced ' $\mathrm{N}$ ', increased ' $\mathrm{C}$ ' and $\mathrm{C}$ : $\mathrm{N}$ ratio due to rapid photosynthesis and growth (Norby et al., 1999) of the plant. Similar change was observed in the present study also wherein, biochemical analysis of chickpea foliage, a $\mathrm{C}_{3}$ plant revealed a significant reduction in leaf nitrogen (over $24.74 \%$ ) when grown under elevated $\mathrm{CO}_{2}$ concentrations compared to ambient.

A significant increase in ' $\mathrm{C}$ ' (over $26.9 \%$ ) and $\mathrm{C}$ : $\mathrm{N}$ ratio (over $58.17 \%$ ) was observed in chickpea foliage under elevated $\mathrm{CO}_{2}$ conditions than ambient condition, which might be due to increased carbon intake by the plants when grown under elevated $\mathrm{CO}_{2}$ conditions. Similar observation was reported by Hughes and Bazzaz (1997) in a common milkweed Asclepia syriaca. The phenolic content in chickpea foliage did not 
differ significantly across $\mathrm{CO}_{2}$ concentrations (Fig. 1). Present study indicated the poor nutritional quality of the food for larvae under elevated $\mathrm{CO}_{2}$ condition over ambient and is in agreement with Srivastava et al. (2002); Goverde and Erhardt (2003).

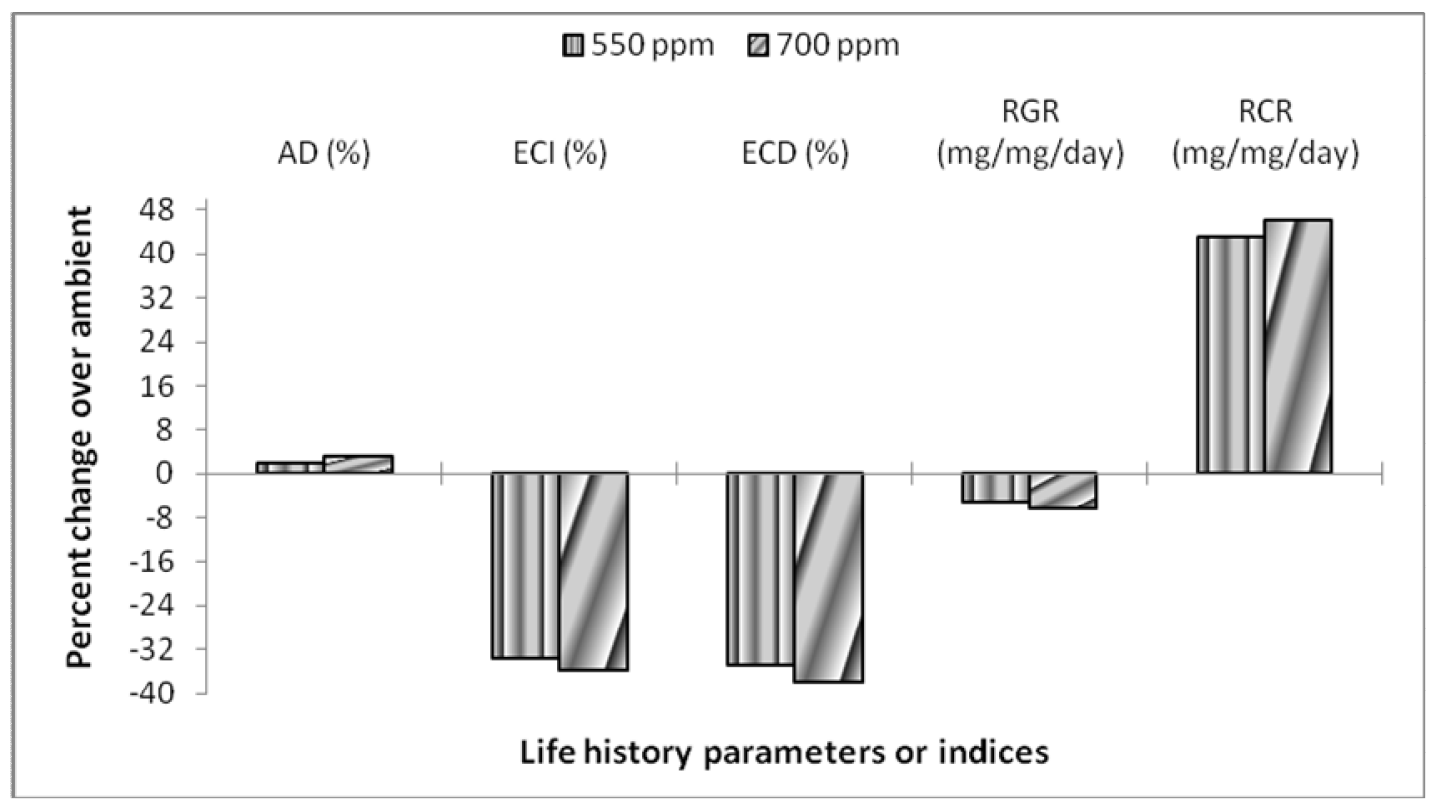

Figure 2. Impact of elevated $\mathrm{CO}_{2}$ on life history parameters or indices of $\mathrm{H}$. armigera

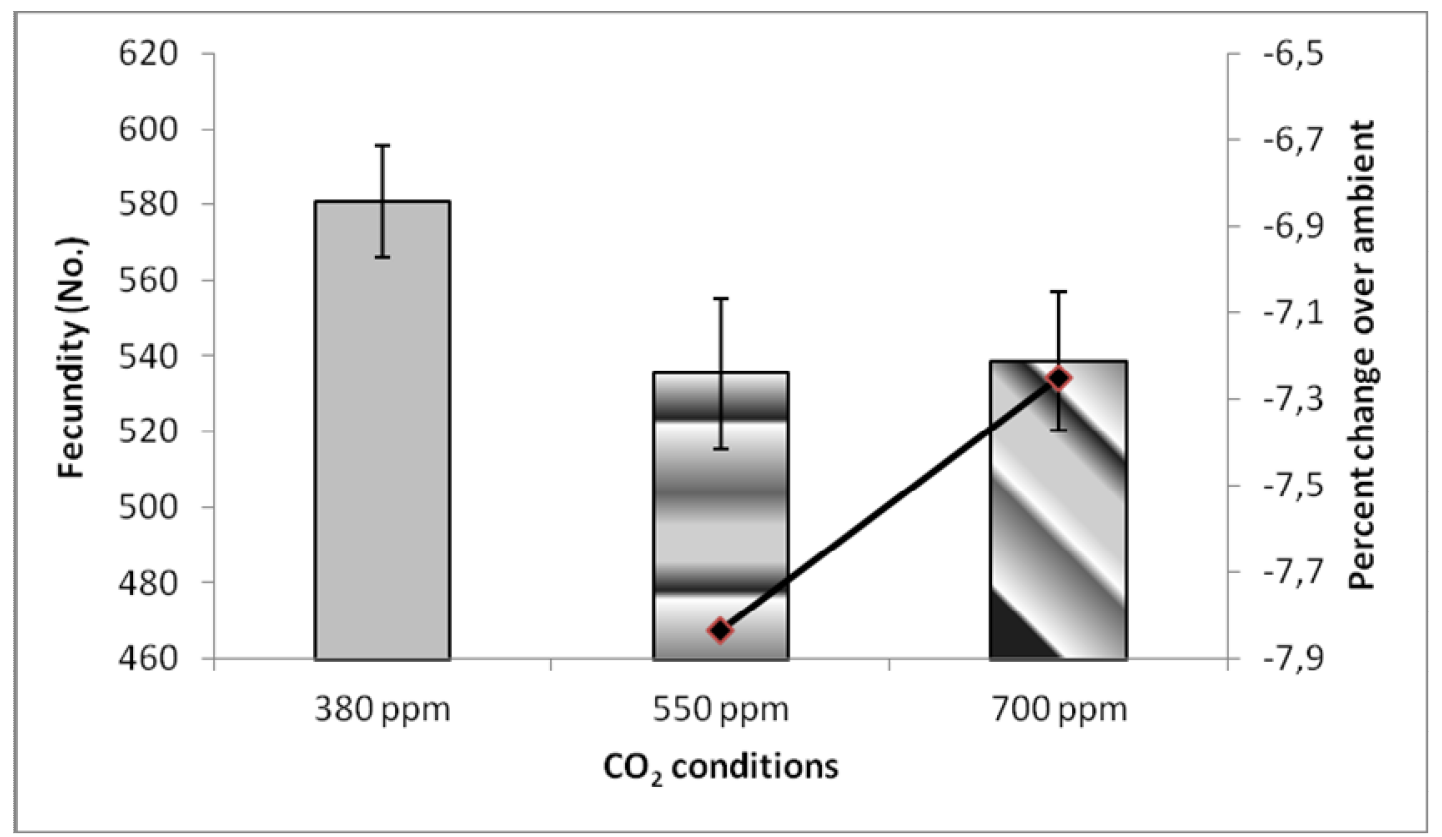

Figure 3. Impact of elevated $\mathrm{CO}_{2}$ on fecundity of $\mathrm{H}$. armigera

Since nitrogen is the chief constituent of proteins and is evident that chickpea plants grown under elevated $\mathrm{CO}_{2}$ concentrations have lower protein content in their tissues, which might result in poor nutritional quality of food. Gram caterpillar, a herbivore 
needs higher protein content for better growth and development. If the nutritional quality of the food is low, it would try to compensate through higher consumption and intake.

In the present study, increased food consumption of $81.67 \%$ by the larvae under elevated $\mathrm{CO}_{2}$ conditions was noticed over ambient. This resulted in increased RCR by $46.18 \%$ in larvae reared under elevated $\mathrm{CO}_{2}$ concentrations. Similar observation was also made by $\mathrm{Wu}$ et al (2006). Increase in larval RCR under elevated $\mathrm{CO}_{2}$ concentrations was attributed to production of fewer allelochemicals reducing the nutritional quality of food thus, promoting phago-stimulatory responses (Scriber and Slanky, 1981). Further, in spite of increased food consumption, RCR and AD (by 3.2 $\%$ ), the gain in the larval weight was mere $4.41 \%$ over ambient. This could be attributed to lower protein content and higher ' $\mathrm{C}$ ' content and ' $\mathrm{C}$ : $\mathrm{N}$ ' ratio in the plant tissues resulting reduced efficiency in the conversion of ingested food (33\%) and digested food $(38 \%)$ by the larvae grown under elevated $\mathrm{CO}_{2}$ concentrations over ambient.

Due to poor efficiency of both ingested and digested food, much of the food consumed was resulted in higher quantity release of fecal matter (about $60 \%$ ) compared to ambient $\mathrm{CO}_{2}$. Similar observations were made by Chen et al, 2007 who recorded 46.3 and 37.8 per cent increased food consumption and feces production, respectively by $H$. armigera when fed on spring wheat $\left(\mathrm{C}_{3}\right.$ plant $)$ under elevated $\mathrm{CO}_{2}$. Further, in spite of higher consumption by larvae under elevated $\mathrm{CO}_{2}$ condition, larvae took approximately one day more to complete their period over ambient. As a result, the relative growth rate (RGR) was reduced by $5-6 \%$ in elevated conditions.

There is a general prediction that the fecundity is the most common parameter for determining the effect of larval food quality on performance of the insect. A significant reduction of fecundity $(6.6 \%)$ was recorded under elevated $\mathrm{CO}_{2}$ over ambient and similar fewer fecund females were reported by Wu et al (2006).

Succinctly, if we put together the above results, it is understood that the dilution of bio-chemical constituents of chickpea foliage caused the poor growth, development and fecundity of $H$. armigera under elevated $\mathrm{CO}_{2}$ conditions. Based on the present study, it can be speculated that, the growth performance of gram caterpillar under elevated $\mathrm{CO}_{2}$ conditions, affects badly resulting in poor perpetuation of the population which might reduce its fitness in subsequent generations.

Acknowledgement: Authors are grateful to Director, CRIDA for his encouragement and thank Mr. Y. B. Srinivasa, IWST, Bangalore for his suggestions in preparing the draft.

\section{REFERENCES}

[1] Ainsworth, E.A, Long, S.P. (2005): What have we learned from 15 years of free-air CO2 enrichment (FACE)? A meta-analytic review of the responses of photosynthesis, canopy. - New Phytology 165:351-71.

[2] Anderson, J.M., Ingran, J.S.I. (1993): Tropical soil biology and fertility: A Handbook of Methods, 2nd edition. - CAB International, Wallingford, UK., 221.

[3] Bhatnager, V.S. (1980): A report on research on the Heliothis complex at ICRISAT (India) 1974-79. Presented at the All India workshop on consolidation of pest management recommendations and guidlines of research. 24-26 Apr. 1980, Udaipur, India. 
[4] Chen, F., Wu, G., Parajulee, M.N., Ge, F. (2007): Long-term impact of elevated carbon dioxide and transgenic $\mathrm{Bt}$ cotton on performance and feeding of three generations of cotton bollworm. - Entomologia Experimentalis et Applicata 124: 27-35.

[5] Goverde, M., Erhardt, A. (2003): Effects of elevated CO2 on development and larval food-plant preference in the butterfly Coenonympha pamphilus (Lepidoptera, Satyridae). - Global Change Biology 9: 74-83.

[6] Guerenstein, P.G., Hildebrand, J.G. (2008): Roles and effects of environmental carbon dioxide in insect life. - Annual Review of Entomology 53: 161-178.

[7] Hughes, L., Bazzaz, F. A. (1997): Effect of elevated CO2 on interactions between the western flower thrips, Frankliniella occidentalis (Thysanoptera: Thripidae) and common milk weed, Asclepias syriaca. - Oecologia 109: 286-290.

[8] Hunter, M. D., (2001): Effect of atmospheric carbon dioxide on insect-plant interactions. - Agriculture and Forest Entomology 3: 153-159.

[9] IPCC. (2007): Summery for policy makers. In Climate change 2007, published for the Intergovernmental Panel on Climate Change. Cambridge University Press, pp 2-18.

[10] Leon Hartwell., Vara Prasad. (2004): Crop response to elevated Carbon dioxide. Encyclopedia of Plant and Crop Science. DOI: 10.1081/E-EPCS 120005566.

[11] McKenzie, H. A. (1994): The Kjeldahl determination of nitrogen: retrospect and prospect. - Analytical Chemistry 13(4): 138.

[12] Norby, R.J., Willschleger, S.D., Gunderson, C.A., Johnson, D.W., Ceulemans, R. (1999): Tree responses to rising $\mathrm{CO} 2$ in field experiments: implications for the future forest. Plant cell and Environment 22: 683-714.

[13] Scriber, J.M., Slansky, F. (1981): The nutritional ecology of immature insects. - Annual Review of Entomology 26: 183-211.

[14] Srinivasa Rao, M., Srinivas, K., Vanaja, M., Rao, G.G.S.N., Venkateswarlu, B., Ramakrishna, Y.S. (2009): Host plant (Ricinus communis Linn.) mediated effects of elevated CO2 on growth performance of two insect folivores. - Current Science 97(7): 1047-1054.

[15] Srivastava A.C., Tiwari L.D., Madan Pal and Sengupta, U.K. (2002): CO2-mediated changes in mungbean chemistry: Impact on plant-herbivore interactions. - Current Science 82(9): 1148-1151.

[16] Vanaja, M., Maheswari, M., Ratnakumar, P., Ramkrishna, Y.S. (2006): Monitoring and Controlling of $\mathrm{CO} 2$ concentrations in open top chambers for better understanding of plants response to elevated CO2 levels. - Indian Journal of Radio \& Space Physiology 35(6): 193-197.

[17] Waldbauer, G.P. (1968): The consumption and utilization of food by insects. -Advance in Insect Physiology 5: 229-288.

[18] Walkley, A., Black, I.A. (1934): An estimation of degtjareff method of determining soil organic matter and proposed modification of chromic acid titration method. - Soil Science 27: 29-38.

[19] Wu, G., Chen, F.J., Ge, F. (2006): Response of multiple generations of cotton bollworm Helicoverpa armigera Hubner, feeding on spring wheat, to elevated CO2. - Journal of Applied Entomology 130(1): 2-9. 